Abstracta Iranica Abstracta Iranica

Revue bibliographique pour le domaine irano-aryen

Volume 25 | 2004

Comptes rendus des publications de 2002

\title{
« Whither the Ilkhanid Army? Ghazan's First Campain into Syria (1299-1300) », in : N. Di Cosmo, éd., Warfare in Inner Asian History (500-1800). Leyde, Brill, 2002, pp. 221-264.
}

\section{Denise Aigle}

\section{OpenEdition}

\section{Journals}

Édition électronique

URL : http://journals.openedition.org/abstractairanica/4409

ISSN : 1961-960X

\section{Éditeur :}

CNRS (UMR 7528 Mondes iraniens et indiens), Éditions de l'IFRI

Édition imprimée

Date de publication : 15 mai 2004

ISSN : 0240-8910

\section{Référence électronique}

Denise Aigle, « « Whither the Ilkhanid Army? Ghazan's First Campain into Syria (1299-1300) », in : N. Di Cosmo, éd., Warfare in Inner Asian History (500-1800). Leyde, Brill, 2002, pp. 221-264. », Abstracta Iranica [En ligne], Volume 25 | 2004, document 120, mis en ligne le 15 mars 2006, consulté le 25 septembre 2020. URL : http://journals.openedition.org/abstractairanica/4409

Ce document a été généré automatiquement le 25 septembre 2020.

Tous droits réservés 
« Whither the Ilkhanid Army? Ghazan's First Campain into Syria (1299-1300) », in : N. Di Cosmo, éd., Warfare in Inner Asian History (500-1800). Leyde, Brill, 2002, pp. 221-264.

Denise Aigle

Cette contribution analyse la première campagne de Ghazan Khan en Syrie. L'A. constate que le processus d'acculturation des Mongols en Iran n'avait pas eu un impact notable dans la sphère militaire. En désaccord avec les thèses de John Masson Smith [ "'Ayn Jālūt : Mamlūk Success or Mongol Failure ?», Harvard Journal of Asiatic Studies, 44 (1984), pp. 307-345], R. Amitaï soutient l'idée que l'armée mongole n'était pas inférieure à celle des Mamelouks, ni en armement, ni en esprit de combat, mais que les Mamelouks avaient des tactiques inconnues des Mongols, ce qui leur avait donné un avantage certain.

\section{INDEX}

Thèmes : 4.1. Histoire médiévale 
AUTEURS

DENISE AIGLE

IFEAD - Damas 